\title{
Supersaturated Calcium Phosphate Rinse
}

National Cancer Institute

\section{Source}

National Cancer Institute. Supersaturated Calcium Phosphate Rinse. NCI Thesaurus.

Code C84398.

An aqueous oral rinse composed of an electrolyte solution supersaturated with

phosphate and calcium ions with antimucositis and analgesic activities. This solution may help relieve mucositis and mucositis-induced pain by restoring the natural electrolyte and $\mathrm{pH}$ balance of human saliva and lubricating mucosal tissues of the mouth, tongue and oropharynx. 